\title{
Paediatric vesicoureteric reflux imaging: where are we? Novel ultrasound-based voiding urosonography
}

\author{
KS Tse *, LS Wong, HY Lau, WS Fok, YH Chan, KW Tang, Susan CH Chan
}

This article was published on $18 \mathrm{Jul}$

2014 at www.hkmj.org.

\section{A B S T R A C T}

Vesicoureteric reflux is an important association of paediatric urinary tract infection. Fluoroscopic micturating cystourethrography and radionuclide cystography have been employed for detecting and grading vesicoureteric reflux. However, both modalities involve ionising radiation, which can pose significant radiation risk to growing children. They also have a lower detection rate due to intermittent fluoroscopic technique in micturating cystourethrography, and lower spatial resolution in radionuclide cystography. Therefore, newer radiation-free ultrasound-based contrast-enhanced voiding urosonography has been developed in Europe for 15 years. This article aimed to summarise the current literature and discuss the first local pilot study in our institution on detection of vesicoureteric reflux by contrast-enhanced voiding urosonography. Contrast-enhanced voiding urosonography is a valid alternative to micturating cystourethrography in assessing vesicoureteric reflux, based on its superior diagnostic performance, reliability, safety, feasibility, and radiation safety for children. Therefore, it should be incorporated in the guideline for investigating paediatric urinary tract infection.

\section{Hong Kong Med J 2014;20:437-43 \\ DOI: $10.12809 / \mathrm{hkmj} 144215$ \\ KS Tse *, FHKCR, FHKAM (Radiology) \\ LS Wong, PDDR, MAS (Sonography) \\ HY Lau, FHKCR, FHKAM (Radiology) \\ WS Fok, MB, BS, FRCR \\ YH Chan, MB, ChB, FRCR \\ KW Tang, FHKCR, FHKAM (Radiology) \\ SCH Chan, FHKCR, FHKAM (Radiology)}

Department of Radiology and Imaging, Queen Elizabeth Hospital, Jordan, Hong Kong

* Corresponding author: sunnytse@ha.org.hk

\section{Introduction}

Urinary tract infection (UTI) is a common emerging paediatric condition. It has a multifactorial aetiology, with multiple host factors implicated in its pathogenesis. Vesicoureteric reflux is considered one of the most important associations of paediatric UTI. Vesicoureteric reflux refers to the abnormal retrograde flow of urine from urinary bladder back into the ureter or, even, to the kidney. It accounts for about $25 \%$ to $40 \%$ of UTIs in children, with no significant difference in the prevalence among boys and girls presenting with UTI, except in infancy. ${ }^{1}$ A local cross-sectional study ${ }^{2}$ demonstrated that vesicoureteric reflux was prevalent in $30 \%$ of boys and $43 \%$ of girls presenting with symptomatic UTI in infancy. It is not only a developmental anomaly related to inadequate length of intravesical submucosal ureter, but also a dysfunctional problem in which many patients have associated bladder emptying and bowel dysfunction. ${ }^{3}$ For decades, it has been thought to be associated with reflux nephropathy and renal scarring. ${ }^{4}$ Nevertheless, there are disputes about the role of vesicoureteric reflux in the development of UTI, ${ }^{5}$ as well as the effectiveness of antibiotic prophylaxis in preventing pyelonephritis and scarring. ${ }^{6}$ Nonetheless, it is recommended to exclude vesicoureteric reflux in high-risk patients, including those with hydronephrosis, renal scarring, or other findings that suggest high-grade vesicoureteric reflux or obstructive uropathy on renal ultrasound, and in those suffering from atypical UTI or complex clinical circumstances. ${ }^{7}$ Conventional reflux imaging modalities for diagnosing the condition include micturating cystourethrography (MCU)/voiding cystourethrography and radionuclide cystography (RNC).

\section{Micturating cystourethrography}

Micturating cystourethrography has been the gold standard of imaging for diagnosing and grading vesicoureteric reflux. It is a fluoroscopic examination utilising radiographic contrast medium and fluoroscopic (X-ray) screening. The procedure involves bladder catheterization and intravesical administration of radiographic contrast via the urinary catheter, followed by fluoroscopic examination of the lower abdomen and pelvis. The presence of opacification of the upper urinary tract 


\section{小兒膀胱輸尿管返流顯像的現況：新式的排尿性 尿道超聲波造影檢查}

\author{
謝健藥、王麗嫦、劉顯宇、霍泳珊、陳彥豪、鄧國穎、陳慈欽
}

膀胱輸尿管返流與小兒泌尿道感染有重要關聯。過往一直使用排尿性 透視膀胱尿道攝影和放射性核素膀胱造影來檢測膀胱輸尿管返流, 並 替其分級。然而, 這兩種方式均涉及電離輻射, 因此會對成長中的兒 童明顯構成輻射風險。此外, 排尿性透視膀胱尿道攝影的間歇性透視 技術的檢測率較低, 而放射性核素膀胱造影的空間分辨率也較低。有 見及此, 在歐洲, 較新的無輻射排尿性尿道超聲波造影檢查已開發了 十五年。本文旨在總結這種造影增強排尿性尿道超聲波造影來檢測膀 胱輸尿管返流的文獻, 並討論在本院中作試點研究的情況。對比增強 排尿性尿道超聲波造影可作為排尿性透視膀胱尿道攝影的有效代替 品; 恣着其優越的診斷性、可靠性、安全性、可行性和對於兒童的安 全輻射性, 此技術能評估膀胱輸尿管返流。因此, 應引入對比增強排 尿性尿道超聲波造影來檢測患上泌尿道感染的兒童。

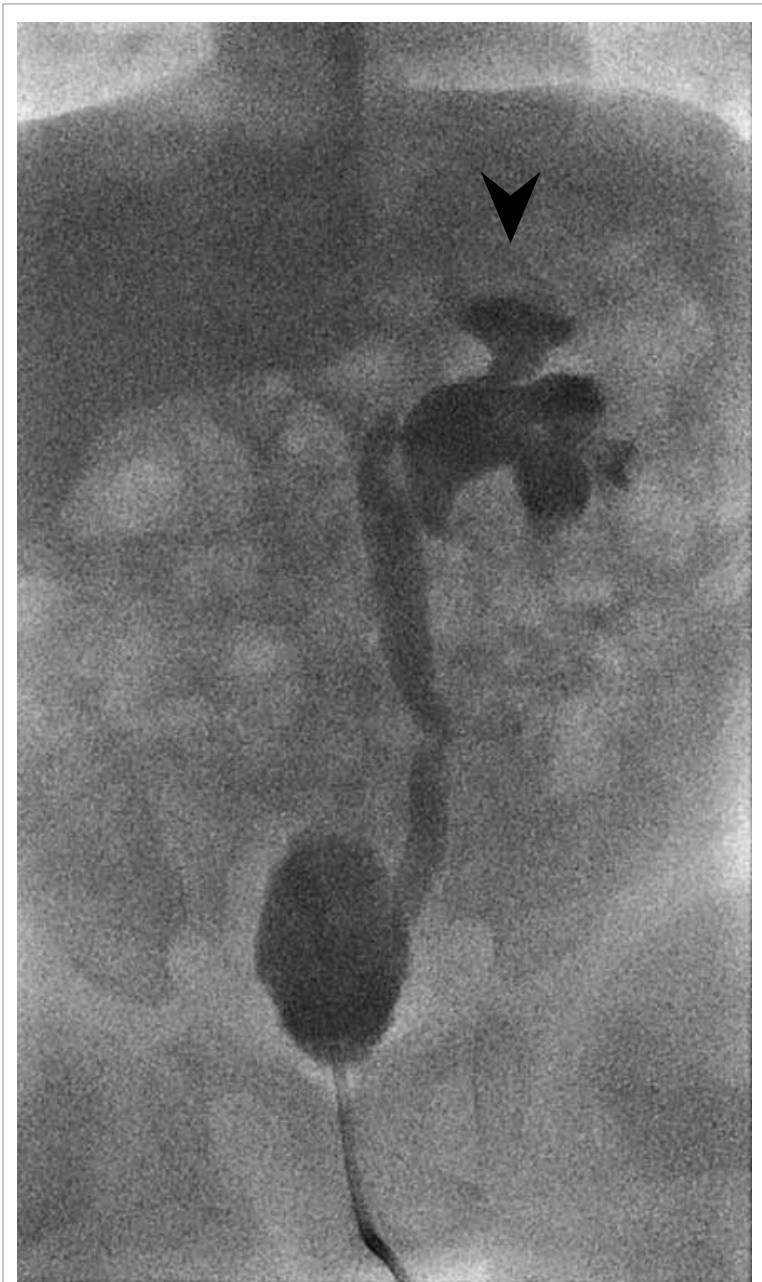

FIG I. Anteroposterior projection of micturating cystourethrography of a 3-year-old boy during voiding phase showing opacification of left renal pelvis and ureter by radiographic contrast (arrowhead), suggesting grade 4 vesicoureteric reflux on the left
TABLE I. International grading of voiding cystourethrography ${ }^{8}$

\begin{tabular}{ll}
\hline Grade & \multicolumn{1}{c}{ Definition } \\
\hline I & Reflux into ureter only \\
II & Reflux into non-dilated renal pelvis \\
III & Reflux into mildly dilated renal pelvis \\
IV & Reflux into moderately dilated renal pelvis \\
V & Reflux into severely dilated renal pelvis with tortuous ureter \\
\hline
\end{tabular}

with radiographic contrast during bladder filling and voiding phases is diagnostic of vesicoureteric reflux (Fig 1). A standardised international system is used for grading the reflux as shown in Table 1. Occurrence of reflux during filling and voiding phases, which represents low-pressure lowvolume and high-pressure high-volume conditions, respectively, has different prognostic implications. ${ }^{9}$ fluoroscopy and, thus, exposure to ionising radiation. The standard mean effective dose of MCU is approximately 0.4 to $0.9 \mathrm{mSv} .^{10}$ To reduce radiation exposure in both patients and operators, intermittent fluoroscopic screening and last image hold on pulsed digital fluoroscopy are employed. Nevertheless, children are more susceptible than adults to the longterm hazards of radiation, because growing tissues in children are more sensitive to radiation effects than the fully mature tissues of adults. Furthermore, children have longer life expectancy during which potential oncogenic effects of radiation may be manifested. ${ }^{10}$ Recent literature shows a dramatic increase in medical radiation burden to children arising from radiological examinations with the expansion of medical imaging. In the United States, the number of computed tomographic examinations doubled for children younger than 5 years of age, and tripled for those aged 5 to 14 years between 1996 and $2005 .^{11}$ It is postulated that medical radiation can contribute to radiation-induced cancers. ${ }^{10}$ Hence, radiation exposure is a major drawback of MCU. Of note, as vesicoureteric reflux is an intermittent phenomenon, ${ }^{12}$ it can sometimes be missed by intermittent fluoroscopic screening techniques. The dilution of small amount of radiographic contrast in the already-dilated collecting system, and obscuration by overlying bowel shadow, also contribute to the lower sensitivity of MCU. ${ }^{12}$

\section{Radionuclide cystography}

Direct RNC also involves bladder catheterization and intravesical administration of radiopharmaceuticals. It carries the advantages of continuous examination of kidneys and bladder during filling phase, and 
lower gonadal radiation dose. ${ }^{13}$ The estimated dose to the ovary is 0.005 to $0.01 \mathrm{mGy}$, and even smaller dose to the testis. ${ }^{14}$ In general, it has comparable diagnostic performance with MCU, with no significant difference in the detection rate. ${ }^{13}$ The mean direct cost of RNC, including the cost of labour, as well as materials and consumables, is also lower than that of MCU. ${ }^{15}$ However, owing to its lower spatial resolution and impaired anatomical delineation, RNC is generally used for follow-up of patients with known vesicoureteric reflux. ${ }^{14}$ It is not recommended as the first diagnostic test for vesicoureteric reflux, particularly in boys due to its limited efficacy in examining the urethral abnormality in detail. Besides, RNC also involves ionising radiation to both children and parents.

\section{Novel technique: contrast- enhanced voiding urosonography}

Ultrasound-based reflux imaging has been investigated in Europe for about 20 years. ${ }^{16}$ This modality obviates exposure of children to ionising radiation and allows prolonged, continuous scanning. ${ }^{17}$ It is now called 'contrast-enhanced voiding urosonography' (ceVUS), previously known as reflux sonography, echocystography, cystosonography, and echo-enhanced cystography. ${ }^{18-20}$ The ceVUS is technically analogous to conventional MCU, in that an ultrasound contrast agent is administered intravesically via the urinary catheter, followed by continuous, alternate examination of the kidneys, urinary bladder, and retrovesical region during filling and voiding phases, as well as the urethra via transperineal or interscrotal approach during voiding phase. The diagnosis of vesicoureteric reflux is determined by the presence of moving echogenic (bright) microbubbles from ultrasound contrast in the upper urinary tract (Fig 2). Its fivetier grading system by Darge and Troeger ${ }^{21}$ is similar to the international reflux system, based on the presence of reflux and dilatation of the collecting system. It allows analogous correlation by the clinicians with the well-established radiographic grading system. The diagnostic performance of ceVUS was only improved since the introduction of stabilised ultrasound contrast agent on intravesical application, ${ }^{20}$ as well as the advances in the ultrasound techniques, namely, harmonic imaging. ${ }^{22}$ Levovist (Levovist Schering, Berlin, Germany) was the firstgeneration stabilised ultrasound contrast composed of palmitic-acid stabilised microbubbles employed in ceVUS. ${ }^{23}$ It was first introduced for intravenous use in assessing cardiac shunts and defects in mid-1990s, and, later, approved for intravesical application. Currently, second-generation ultrasound contrast SonoVue (SonoVue, Bracco, Italy) has several intrinsic advantages over Levovist. ${ }^{24}$ SonoVue is a stabilised aqueous suspension of sulphur

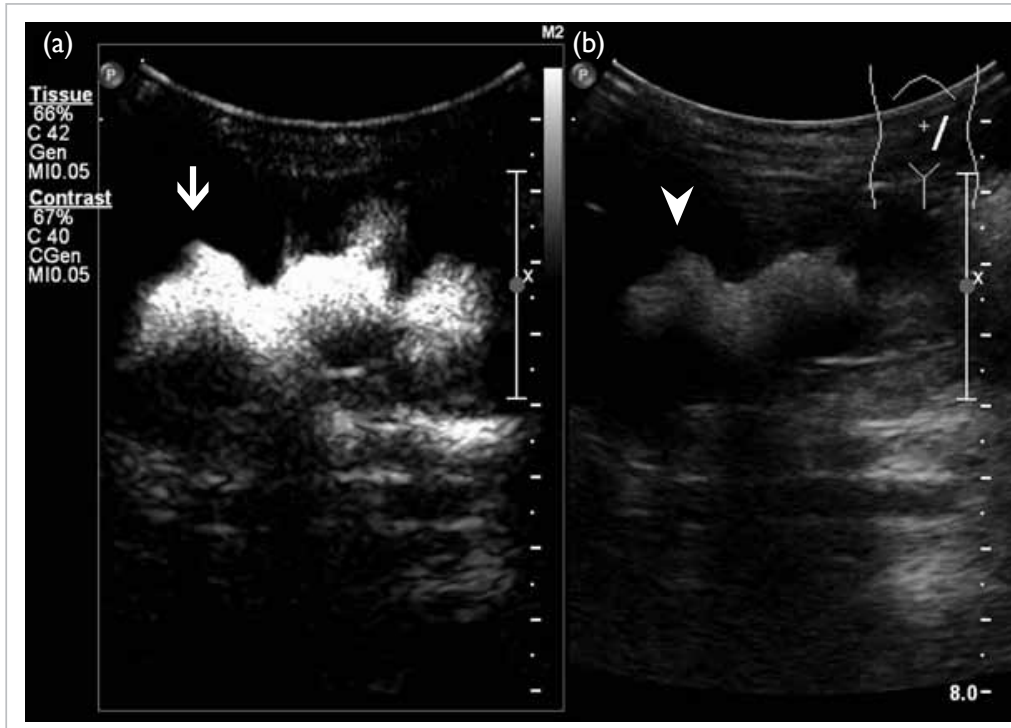

FIG 2. Longitudinal view of left kidney in voiding urosonography of a 16-month-old boy, using C5-2 transducer by transabdominal approach

(a) Contrast-specific harmonic imaging mode with subtraction technique: the presence of echogenic (bright) particles (arrow) in the moderately dilated left renal pelvicalyceal system suggests grade 4 vesicoureteric reflux. (b) Grayscale mode: the particles from the ultrasound contrast (arrowhead) at the left renal pelvicalyceal system appear slightly hyperechoic (bright)

hexafluoride microbubbles with a phospholipid shell, which resonate by asymmetric contraction and expansion, and strongly increase the ultrasound backscatter allowing visualisation. It is not readily soluble in water, and, hence, remains stable for up to 6 hours. ${ }^{25}$ In addition to the improved intrinsic property of ultrasound contrast, tissue harmonic imaging technique is now employed in ultrasound imaging. Tissue harmonic imaging is based on the phenomenon of non-linear distortion of an acoustic signal as the ultrasound wave insonates and travels through the body tissues. It improves contrast and spatial resolution, and reduces artefacts compared with conventional grayscale ultrasound. ${ }^{26}$ Together with subtraction technique, contrast-specific harmonic imaging mode further increases the conspicuity of the microbubbles.

With the application of newer-generation ultrasound contrast agent and ultrasound techniques, ceVUS is currently regarded as a valid, radiation-free imaging modality for examining vesicoureteric reflux in Europe. ${ }^{27}$ In addition to the previous literature, the first local pilot comparative study in Hong Kong by the authors also supports ceVUS as a valid alternative to MCU in most clinical indications, based on its high efficacy, reliability, high safety profile and feasibility, and radiation safety for children. ${ }^{28}$

\section{High diagnostic efficacy}

The utilisation of stabilised ultrasound contrast 
agent has revolutionised ultrasound-based reflux imaging, by enabling prolonged sonographic examination of the upper urinary tract. Darge ${ }^{29}$ has confirmed the diagnostic performance of ceVUS by the first-generation stabilised ultrasound contrast Levovist. Using MCU as the reference method, the sensitivity of ceVUS ranged from $57 \%$ to $100 \%$, and specificity from $85 \%$ to $100 \%$. The diagnostic accuracy, measuring the concordance of both positive and negative cases, ranged from $78 \%$ to $96 \%$. Approximately $10 \%$ of all reflux units were diagnosed by MCU alone, and $9 \%$ were diagnosed by ceVUS alone. However, the majority of reflux units missed on ceVUS were of low grade, while most missed refluxes on MCU were of medium-to-high grade. $^{29}$ The intermittent nature of vesicoureteric reflux, together with intermittent fluoroscopy, and dilution of radiographic contrast were postulated to result in lower detection rate of high-grade reflux on MCU. On the other hand, the lower detection rate of low-grade reflux on ceVUS is attributed to the difficulty in visualising retrovesical regions and nondilated ureter related to the acoustic shadow casted by the intravesical contrast.

Currently, the second-generation contrast SonoVue-enhanced VUS has superior sensitivity ranging from $80 \%$ to $100 \%$, and a specificity of $77 \%$ to 97\% (Table 2)..$^{27,28,30-34}$ Diagnostic accuracy is similar to that of Levovist, at about $80 \%$ to $98 \% .^{27,28,30-34}$ Moreover, SonoVue-enhanced VUS has consistently higher reflux detection rate than MCU. Data show that MCU misses $6 \%$ to $62 \%$ of all reflux units. In the study by Ključevšek et $\mathrm{al}^{31} 26$ (62\%) out of 42 reflux units were additionally identified by ceVUS alone, but none by MCU alone. On the other hand, ceVUS misses only $0 \%$ to $12 \%$ of all reflux units. ${ }^{27,28,30-34}$ Similarly, our pilot study showed that ceVUS achieved $100 \%$ sensitivity and $85 \%$ specificity, as well as $85 \%$ accuracy, in 31 patients (ie 62 kidneyureter units). Higher detection rate was, once again, achieved by ceVUS, where MCU had missed $64 \%$ of all reflux units (9 out of 14 reflux units), half of which were of high grade. ${ }^{28}$ Therefore, ceVUS is not only highly concordant with MCU on reflux detection, but also more sensitive than MCU.

\section{Reliability}

Sonographic techniques entail specialised scanning and interpretation skills, and are considered to be operator-dependent. According to a recent review by Prasad and Cheng, ${ }^{35}$ the techniques of ceVUS remained operator-dependent and required highly skilled sonographers. Hence, our pilot study had specifically examined the reliability of ceVUS by independent review of the saved images and cine video clips of all the ceVUS examinations by two operators after study completion. Perfect interobserver agreement was achieved, with Cohen's Kappa statistics of $1.0(\mathrm{P}<0.001)$. Therefore, with harmonic imaging and modified ultrasound techniques, ceVUS has good reliability in diagnosing vesicoureteric reflux in children.

\section{Safety profile and feasibility}

Voiding urosonography involves intravesical application of ultrasound contrast and continuous sonographic examination. The ultrasound contrast is not administered intravenously and, hence, systemic complications are extremely rare. In a recent European territory-wide questionnairebased survey, ${ }^{36}$ there were no allergic reactions or systemic complications related to SonoVue in 5079 paediatric ceVUS examinations performed in 45 European centres. Only few minor complications related to catheterization were encountered. Our pilot study also confirmed the high safety profile of SonoVue-enhanced VUS. No complications related to the contrast agent, catheterization, or infection were noticed. ${ }^{28}$ Apart from high safety profile, technical feasibility is another advantage of ceVUS. As mentioned earlier, ceVUS is technically

TABLE 2. Diagnostic performance of voiding urosonography with intravesical second-generation ultrasound contrast agent, SonoVue, in primary diagnostic comparative studies using micturating cystourethrography as reference method ${ }^{27,28,30-34}$

\begin{tabular}{|c|c|c|c|c|c|}
\hline Primary studies & $\begin{array}{l}\text { No. of PUUs } \\
\text { (patients) }\end{array}$ & $\begin{array}{c}\text { Sensitivity } \\
(\%)^{\star}\end{array}$ & $\begin{array}{c}\text { Specificity } \\
(\%)^{\star}\end{array}$ & $\begin{array}{l}\text { No. }(\%) \text { of PUUs } \\
\text { missed by MCU }\end{array}$ & $\begin{array}{l}\text { No. (\%) of PUUs } \\
\text { missed by VUS }\end{array}$ \\
\hline Tse et al, ${ }^{28} 2013$ & $62(31)$ & 100 & 85 & $9(64)$ & 0 \\
\hline Ključevšek et al, ${ }^{31} 2012$ & $132(66)$ & 100 & 78 & $26(62)$ & 0 \\
\hline Kis et $a l,{ }^{33} 2010$ & $366(183)$ & 86 & 86 & $37(26)$ & $14(10)$ \\
\hline Papadopoulou et al, ${ }^{27} 2009$ & $463(228)$ & 80 & 77 & $90(56)$ & $14(9)$ \\
\hline Papadopoulou et al,,$^{30} 2005$ & $137(70)$ & 96 & 78 & $25(52)$ & $1(0.4)$ \\
\hline Ascenti et al, ${ }^{32} 2004$ & $160(80)$ & 100 & 97 & $3(6)$ & 0 \\
\hline Darge et al, ${ }^{34} 2004$ & $84(40)$ & 85 & 92 & $5(20)$ & $3(12)$ \\
\hline
\end{tabular}

Abbreviations: MCU = micturating cystourethrography; PUU = pelvic-ureter unit; VUS = voiding urosonography

* Calculation based on MCU as the reference method of examination 
analogous with MCU, except that it involves sonographic examination of the urinary tract instead of fluoroscopy. In terms of manpower, a ceVUS examination requires a radiologist and two sonographers, which is similar to that for MCU. Therefore, the examination duration and manpower involved in ceVUS are similar to that for MCU. ${ }^{28}$ Finally, the dosage of SonoVue in each ceVUS examination is $0.8 \mathrm{~mL}$ to $1 \mathrm{~mL}$, which is adequate for at least three cycles of filling and voiding phases. Therefore, a vial of SonoVue can be shared among several patients in each session, thus, allowing effective usage of the contrast agent. ${ }^{28}$

\section{Radiation protection}

With the use of ultrasound examination in ceVUS, many clinical indications of MCU can be performed by ceVUS. The ceVUS had been incorporated in the joint guideline for urological examination by the European Society of Urogenital Radiology (ESUR)

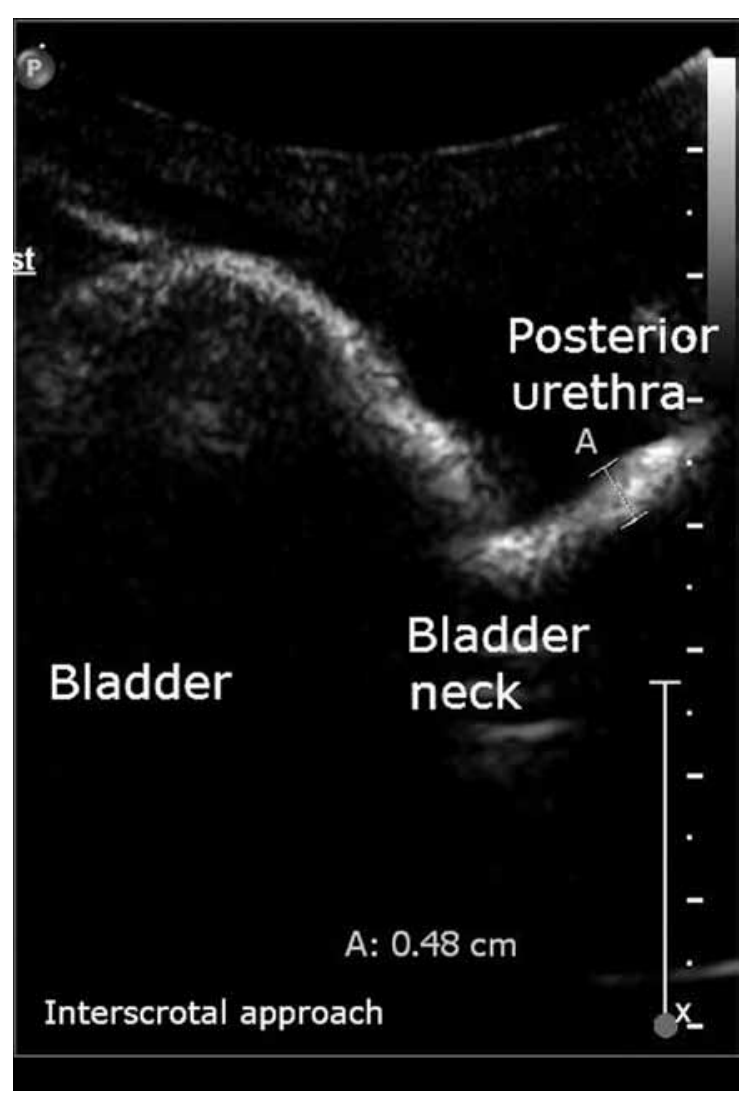

FIG 3. Sagittal view of urinary bladder base and posterior urethra in a 2-year-old boy, using C5-2 transducer by interscrotal approach

The bladder base and urethra can be demonstrated by placing the transducer in the midline over the scrotal region. The urethra is visualised as a tubular structure arising from the bladder base, and its calibre and distensibility can be evaluated. The calibre of posterior urethra, as marked, is normal in this patient and European Society of Paediatric Radiology (ESPR) in 2007. ${ }^{37}$ The indications of ceVUS include followup examination of known vesicoureteric reflux, investigation of UTI in girls, as well as screening for familial history of vesicoureteric reflux and fetal hydronephrosis. With the application of urethral imaging in ceVUS, examination of the urethra is technically feasible (Fig 3). Duran et al ${ }^{38}$ revealed that diagnosis of urethral pathologies, such as posterior urethral valve, diverticulum of prostatic utricle, and anterior urethral stricture could be achieved by using interscrotal and transperineal approaches in boys. The application of ceVUS has extended to investigation of UTI in boys and urethral imaging in genitogram in the ESUR and ESPR guideline 2012. ${ }^{39}$

Micturating cystourethrography is by far the most common fluoroscopic examination performed in children, accounting for $40 \%$ of the examinations. ${ }^{40}$ In a recent study on radiation dose of paediatric MCU by Sulieman et $\mathrm{al}^{41}$ the mean entrance surface dose for MCU with positive reflux was $1.45 \mathrm{mGy}$, and negative reflux was $1.05 \mathrm{mGy}$. As gonads were inside the radiation field during the examination, there was a higher organ equivalent dose to ovaries $(0.44 \mathrm{mSv})$ and testes $(0.33 \mathrm{mSv})$ than to thyroid $(0.006 \mathrm{mSv})$. The estimated risks of malignancy of ovaries and testes were $4.4 \times 10^{-7}$ and $3.3 \times 10^{-7}$, respectively. Although the risks are small, cumulative radiation exposure and radiation to developing gonads are inevitable in patients with positive reflux who require repeat examinations for follow-up. Taking $20 \%$ as the positive rate of MCU, a large proportion of patients and parents are exposed to ionising radiation for ruling out vesicoureteric reflux. As ceVUS can provide most of the diagnostic information offered by MCU, it can be a valid radiation-free alternative to $\mathrm{MCU}$. According to Giordano et $\mathrm{al}^{42}$ radiation dose has significantly reduced since the application of ceVUS in routine clinical practice.

\section{Limitations of contrast-enhanced voiding urosonography}

As discussed in the previous section, the acoustic shadowing produced by the high concentration of ultrasound contrast can obscure the retrovesical region and, thus, decrease the sensitivity of ceVUS in detecting grade I reflux. ${ }^{29}$ This is remedied by dilution of ultrasound contrast by continuous saline infusion, and is best assessed during the second cyclical examination. $^{28}$ Besides, ceVUS has limitation in those examinations that require detailed anatomical assessment, such as in evaluation of recto-urethral fistula in distal loopogram in neonates with anorectal malformation. ${ }^{28}$ However, the majority of indications of MCU, as mentioned in previous sections, can also be performed by ceVUS. 


\section{Conclusion}

In the era of heightened radiation awareness and protection, radiation doses to infants and children should be kept as low as reasonably achievable. Contrast-enhanced voiding urosonography using intravesical ultrasound contrast agent should be introduced as a valid alternative diagnostic modality for detecting vesicoureteric reflux, based on its radiation-free, highly efficacious, reliable, and safe characteristics ${ }^{43}$; MCU can be reserved for patients requiring detailed anatomical assessment.

\section{Declaration}

No conflicts of interest were declared by the authors.

\section{References}

1. Sargent MA. What is the normal prevalence of vesicoureteric reflux? Pediatr Radiol 2000;30:587-93.

2. Fong KW, Wong SN. Symptomatic urinary tract infection in children: experience in a regional hospital in Hong Kong. Hong Kong J Paediatr 2004;9:30-6.

3. Koff SA, Wagner TT, Jayanthi VR. The relationship among dysfunctional elimination syndromes, primary vesicoureteral reflux and urinary tract infections in children. J Urol 1998;160:1019-22.

4. Bailey RR. The relationship of vesico-ureteric reflux to urinary tract infection and chronic pyelonephritis-reflux nephropathy. Clin Nephrol 1973;1:132-41.

5. Ditchfield MR, De Campo JF, Cook DJ, et al. Vesicoureteral reflux: an accurate predictor of acute pyelonephritis in childhood urinary tract infection? Radiology 1994;190:4135.

6. Pennesi M, Travan L, Peratoner L, et al. North East Italy Prophylaxis in VUR study group. Is antibiotics prophylaxis in children with vesicoureteral reflux effective in preventing pyelonephritis and renal scars? A randomized, controlled trial. Pediatrics 2008;121:e1489-94.

7. Subcommittee on Urinary Tract Infection, Steering Committee on Quality Improvement and Management, Roberts KB. Urinary tract infection: clinical practice guideline for the diagnosis and management of the initial UTI in febrile infants and children 2 to 24 months. Pediatrics 2011;128:595-610.

8. Lebowitz RL, Olbing H, Parkkulainen KV, Smellie JM, Tamminen-Mobius TE. International system of radiographic grading of vesicoureteric reflux. International Reflux Study in Children. Pediatr Radiol 1985;15:105-9.

9. Arsanjani A, Alagiri M. Identification of filling versus voiding reflux as predictor of clinical outcome. Urology 2007;70:351-4.

10. Perisinakis K, Raissaki M, Damilakis J, Stratakis J, Neratzoulakis J, Gourtsoyiannis N. Fluoroscopy-controlled voiding cystourethrography in infants and children: are the radiation risks trivial? Eur Radiol 2006;16:846-51.

11. Miglioretti DL, Johnson E, Williams A, et al. The use of computed tomography in pediatrics and the associated radiation exposure and estimated cancer risk. JAMA Pediatr 2013;167:700-7.

12. Sukan A, Bayazit AK, Kibar M, et al. Comparison of direct radionuclide cystography and voiding direct cystography in the detection of vesicoureteral reflux. Ann Nucl Med
2003;17:549-53.

13. Unver T, Alpay H, Biyikli NK, Ones T. Comparison of direct radionuclide cystography and voiding cystourethrography in detecting vesicoureteral reflux. Pediatr Int 2006;48:28791.

14. Fettich J, Colarinha P, Fischer S, et al. Guidelines for direct radionuclide cystography in children. Eur J Nucl Med Mol Imaging 2003;30:39-44.

15. Medina LS, Aquirre E, Altman NR. Vesicoureteral reflux imaging in children: comparative cost analysis. Acad Radiol 2003;10:139-44.

16. Atala A, Wible JH, Share JC, Carr MC, Retik AB, Mandell J. Sonography with sonicated albumin in the detection of vesicoureteral reflux. J Urol 1993;150:756-8.

17. Valentini AL, De Gaetano AM, Destito C, Marino V, Minordi LM, Marano P. The accuracy of voiding urosonography in detecting vesico-ureteral reflux: a summary of existing data. Eur J Pediatr 2002;161:380-4.

18. Radmayr C, Klauser A, Pallwein L, Zurnedden D, Bartsch G, Frauscher F. Contrast enhanced reflux sonography in children: a comparison to standard radiological imaging. J Urol 2002;167:1428-30.

19. Escape I, Martinez J, Bastart F, Solduga C, Sala P. Usefulness of echocystography in the study of vesicoureteral reflux. J Ultrasound Med 2001;20:145-9.

20. Bosio M. Cystosonography with echocontrast: a new imaging modality to detect vesicoureteric reflux in children. Pediatr Radiol 1998;28:250-5.

21. Darge K, Troeger J. Vesicoureteral reflux grading in contrast-enhanced voiding urosonography. Eur J Radiol 2002;43:122-8.

22. Tranquart F, Grenier N, Eder V, Pourcelot L. Clinical use of ultrasound tissue harmonic imaging. Ultrasound Med Biol 1999;25:889-94.

23. Fritzsch T, Schlief R. Levovist. Drugs Fut 1995;20:12247.

24. Schneider M. SonoVue, a new ultrasound contrast agent. Eur Radiol 1999;9 Suppl 3:347S-348S.

25. Rossling G. Physico-chemical properties of Levovist. Proceedings of the 2nd European Meeting on Sonographic Diagnosis of Vesicoureteral Reflux; 2000 Mar; Heidelberg, Germany.

26. Shapiro RS, Wagreich J, Parsons RB, Stancato-Pasik A, Yeh HC, Lao R. Tissue harmonic imaging sonography: evaluation of image quality compared with conventional sonography. Am J Roentgenol 1998;171:1203-6.

27. Papadopoulou F, Anthopoulou A, Siomou E, Efremidis S, Tsamboulas C, Darge K. Harmonic voiding urosonography with a second-generation contrast agent for the diagnosis of vesicoureteral reflux. Pediatr Radiol 2009;39:239-44.

28. Tse KS, Wong LS, Fan TW, et al. New radiation-free era in reflux imaging for paediatric urinary tract infection (UTI): voiding urosonography with intravesical ultrasound contrast-first local pilot study. Paper presented at 2013 Hospital Authority Convention; 2013 May 15-16; Hong Kong.

29. Darge K. Voiding urosonography with US contrast agents for the diagnosis of vesicoureteric reflux in children. II. Comparison with radiological examinations. Pediatr Radiol 2008;38:54-63; quiz 126-7.

30. Papadopoulou F, Katzioti F, Arkoumani E, et al. Voiding urosonography harmonic imaging with 2nd generation contrast agent for the diagnosis of reflux [abstract]. Pediatr Radiol 2005;35:130S. 
31. Ključevšek D, Battelino N, Tomažič M, Kersnik Levart T. A comparison of echo-enhanced voiding urosonography with X-ray voiding cystourethrography in the first year of life. Acta Paediatr 2012;101:e235-9.

32. Ascenti G, Zimbaro G, Mazziotti S, et al. Harmonic US imaging of vesicoureteric reflux in children: usefulness of a second generation US contrast agent. Pediatr Radiol 2004;34:481-7.

33. Kis E, Nyitrai A, Varkonyi I, et al. Voiding urosonography with second-generation contrast agent versus voiding cystourethrography. Pediatr Nephrol 2010;25:2289-93.

34. Darge K, Beer M, Gordjani N, Riedmiller H. Contrastenhanced voiding urosonography with the use of a 2nd generation US contrast medium: preliminary results. Pediatr Radiol 2004;34:97S.

35. Prasad MM, Cheng EY. Radiographic evaluation of children with febrile urinary tract infection: bottom-up, top-down, or none of the above? Adv Urol 2012;2012:716739.

36. Riccabona M. Application of a second-generation US contrast agent in infants and children-a European questionnaire-based survey. Pediatr Radiol 2012;42:147180.

37. Riccabona M, Avni FE, Blickman JG, et al. Imaging recommendations in paediatric uroradiology: minutes of the ESPR workgroup session on urinary tract infection, fetal hydronephrosis, urinary tract ultrasonography and voiding cystourethrography, Barcelona, Spain, June 2007. Pediatr Radiol 2008;38:138-45.
38. Duran C, Valera A, Alguersuari A, et al. Voiding urosonography: the study of the urethra is no longer a limitation of the technique. Pediatr Radiol 2009;39:124-31.

39. Riccabona M, Avni FE, Damasio MB, et al. ESPR Uroradiology Task Force and ESUR Paediatric Working Group-Imaging recommendations in paediatric uroradiology, part V: childhood cystic kidney disease, childhood renal transplantation and contrast-enhanced ultrasonography in children. Pediatr Radiol 2012;42:127583.

40. Schneider K, Kruger-Stollfuss I, Ernst G, Kohn NM. Paediatric fluoroscopy-a survey of children's hospitals in Europe. I. Staffing, frequency of fluoroscopic procedures and investigation technique. Pediatr Radiol 2001;31:23846.

41. Sulieman A, Theodorou K, Vlychou M, et al. Radiation dose measurement and risk estimation for paediatric patients undergoing micturating cystourethrography. Br J Radiol 2007;80:731-7.

42. Giordano M, Marzolla R, Puteo F, Scianaro L, Caringella DA, Depalo T. Voiding urosonography as first step in the diagnosis of vesicoureteral reflux in children: a clinical experience. Pediatr Radiol 2007;37:674-7.

43. Wong LS, Tse KS, Fan TW, et al. Voiding urosonography with second-generation ultrasound contrast versus micturating cystourethrography in the diagnosis of vesicoureteric reflux. Eur J Pediatr 2014 Mar 23. Epub ahead of print.

\section{Answers to CME Programme Hong Kong Medical Journal August 2014 issue}

Hong Kong Med J 2014;20:285-9

\section{Severe acute pyelonephritis: a review of clinical outcome and risk factors for mortality}
A
1. True
2. False
3. False
4. True
5. True
B
1. False
2. True
3. False
4. False
5. True

Hong Kong Med J 2014;20:325-30

\section{Immunotherapy for peanut allergy}
A
1. True
2. False
3. False
4. False
5. True
B
1. False
2. True
3. False
4. True
5. False 